OPEN ACCESS

Edited by: Alexandr Bazhin,

Klinikum der Universität

München, Germany

Reviewed by: Ivan Shevchenko,

Ludwig-Maximilians-Universität

München, Germany

Marie-Andree Forget,

University of Texas MD Anderson

Cancer Center, United States

*Correspondence:

Yiyi Yan

yan.yiyi@mayo.edu

Specialty section:

This article was submitted

to Cancer Immunity

and Immunotherapy,

a section of the journal

Frontiers in Immunology

Received: 15 May 2018

Accepted: 13 July 2018

Published: 27 July 2018

Citation:

Yan $Y$, Kumar $A B$, Finnes $H$, Markovic SN, Park S. Dronca RS and

Dong H (2018) Combining Immune

Checkpoint Inhibitors With

Conventional Cancer Therapy.

Front. Immunol. 9:1739. doi: 10.3389/fimmu.2018.01739

\section{Combining Immune Checkpoint Inhibitors With Conventional Cancer Therapy}

\author{
Yiyi Yan ${ }^{1 *}$, Anagha Bangalore Kumar ${ }^{2}$, Heidi Finnes ${ }^{3}$, Svetomir N. Markovic', Sean Park ${ }^{4}$, \\ Roxana S. Dronca ${ }^{5}$ and Haidong Dong ${ }^{2,6}$ \\ 'Division of Medical Oncology, Mayo Clinic, Rochester, MN, United States, 2 Department of Immunology, Mayo Clinic, \\ Rochester, MN, United States, ${ }^{3}$ Department of Pharmacy, Mayo Clinic, Rochester, MN, United States, ${ }^{4}$ Department of \\ Radiation Oncology, Mayo Clinic, Rochester, MN, United States, ${ }^{5}$ Division of Hematology and Medical Oncology, Mayo \\ Clinic, Jacksonville, FL, United States, ${ }^{6}$ Department of Urology, Mayo Clinic, Rochester, MN, United States
}

Immune checkpoint inhibitors (ICls) have recently revolutionized cancer treatment, providing unprecedented clinical benefits. However, primary or acquired therapy resistance can affect up to two-thirds of patients receiving ICls, underscoring the urgency to elucidate the mechanisms of treatment resistance and to design more effective therapeutic strategies. Conventional cancer treatments, including cytotoxic chemotherapy, radiation therapy, and targeted therapy, have immunomodulatory effects in addition to direct cancer cell-killing activities. Their clinical utilities in combination with ICls have been explored, aiming to achieve synergetic effects with improved and durable clinical response. Here, we will review the immunomodulatory effects of chemotherapy, targeted therapy, and radiation therapy, in the setting of $\mathrm{ICl}$, and their clinical implications in reshaping modern cancer immunotherapy.

Keywords: immunotherapy, chemotherapy, targeted therapy, radiotherapy, combination therapy

\section{INTRODUCTION}

Deeper understanding in the regulatory mechanisms of antitumor immunity, especially the identification of immune checkpoint pathways, has led to the success of modern immunotherapy. The past decade has witnessed a revolution in cancer therapy since the introduction of immune checkpoint inhibitors (ICIs), including anti-CTLA4 antibody and anti-PD-1/PD-L1 antibody. These antibodies have reshaped the landscape of treatments in various types of cancers, including melanoma, renal cell cancer, colorectal cancer (CRC), and non-small-cell lung cancer (NSCLC). However, it is estimated that up to $60-70 \%$ of patients do not respond to single-agent ICI therapy (1-7). To address this clinical challenge, different conventional cancer treatment modalities have been tested in combination with ICIs to achieve synergetic effects and to overcome the resistance to immunotherapy. Although some of these approaches have provided clinical benefits, the lack of knowledge in the functional interactions between conventional cancer therapies and immune checkpoint blockades at the molecular level remains a crucial hurdle in developing rational and optimal combination strategies. In this article, we will review the immune-regulatory effects of conventional cancer treatments and their clinical applications in combination with immune checkpoint blockades and future challenges.

\section{COMBINATION OF IMMUNOTHERAPY AND CHEMOTHERAPY}

\section{Immunomodulatory Impact of Cytotoxic Chemotherapy}

It has long been speculated that the immunoregulatory properties of conventional cytotoxic chemotherapy contribute to the antitumoral effects of these agents, in addition to direct tumor killing 
(8). Although the mechanisms are yet to be fully understood, chemotherapy can regulate antitumor $\mathrm{T}$ cell response through increasing tumor antigenicity, inducing immunogenic cell death (ICD), disrupting immune suppressive pathways, and enhancing effector T-cell response (9-12).

Chemotherapy executes direct cancer killing via multiple mechanisms, including causing DNA damage, inhibiting DNA replication, and preventing mitosis (13). The induced tumor cell death further elicits systemic and intratumoral immune responses, contributing to the antitumor immunity. Chemotherapy enhances the antigenicity of the tumors through the increase of mutation burden and neoantigen load (such as in NSCLC and other various malignancies), which are correlated with higher responses to ICI therapy $(14,15)$. Some chemotherapy drugs upregulate MHC class 1 expression to increase antigen presentation $(16,17)$. In addition, chemotherapy drugs promote dendritic cell maturation and enhance the T cell activation by DCs (18). Chemotherapy also promotes ICD by releasing damage-associated molecular patterns, which can generate effector immune response when bound to pattern-recognition receptor. Experiments in animal models have suggested that some chemotherapy drugs induce the expression of PD-L1 on ovarian cancer cells (19).

Cytotoxic chemotherapy is regarded as immunosuppressive due to its dose-limiting myelosuppression. However, recent studies have demonstrated that it also can disrupt suppressive pathways. These immunosuppressive subsets play critical roles in downregulating the antitumor T-cell response and in promoting resistance to ICI treatments. Lymphodepletion resulted after chemotherapy can potentiate antigen-specific T-cell responses, therefore, augment antitumor immunity, particularly during the recovery phase from lymphopenia. Lymphodepletion can eliminate regulatory T cells (Treg) and other immunosuppressive cell subsets, such as myeloid-derived suppressor cells (MDSCs) (20-22) and tumor-associated macrophages (TAMs) (23). For instances, cyclophosphamide eliminates Treg and improves overall survival when combined with immunotherapy in a colon cancer models (24). Doxorubicin eliminates MDSCs and enhances the efficacy of immunotherapy in breast cancer (25). Reductions of these immunosuppressive populations in the tumor microenvironment of glioblastoma, synergize with antiPD-1 therapy, and enhance the antitumor immunity $(26,27)$. The elimination of these immunosuppressive cells will increase the availability of survival and proliferative cytokines for T cells and lower the threshold for T-cell activation. Chemotherapeutic reagents also promote the polarization of Th1/Th2 and enhance the proliferation of T-lymphocytes in patients with advanced solid cancers (such as renal cell carcinoma, colon cancer, and ovarian cancer) $(28,29)$. Over the past decade, multiple studies have shown that different types of chemotherapy drugs can modulate the antitumor immunity in various mechanisms (9).

Given the extensive roles of chemotherapy in regulating the antitumor immune response, it is safe to hypothesize that the addition of chemotherapy to ICI may further enhance the activities of cytotoxic T cells with improved clinical outcomes. Over the past few years, chemoimmunotherapy (CIT) combination has attracted attention from clinicians and researchers and has been investigated in multiple clinical trials.

\section{Clinical Studies With CIT Combinations}

Chemotherapy in combination with immunotherapy (CIT) has been studied in multiple solid tumors, largely in NSCLC, providing broadened treatment options with improved outcomes.

The combination of pembrolizumab with pemetrexed and carboplatin has been evaluated in KEYNOTE-021, a multicenter phase $1 / 2$ study, in patients with NSCLC. In the phase 1 study (30), pembrolizumab in combination with either carboplatin and paclitaxel, or carboplatin and paclitaxel plus bevacizumab, or carboplatin and pemetrexed was investigated, with overall response rate (ORR) of 52, 48, and 71\%, respectively, irrespective of PD-L1 expression levels. These results led to the phase 2 study, evaluating the clinical outcome of pembrolizumab in combination with carboplatin and pemetrexed (31). A total of 123 chemotherapy-naïve nonsquamous NSCLC patients were randomized to chemotherapy alone, or chemo-pembrolizumab combination. Indefinite pemetrexed maintenance therapy was allowed for patients in chemotherapy alone group, and maintenance therapy with indefinite pemetrexed and up to 24 months of pembrolizumab was allowed for patients in chemo-pembrolizumab combination group. A significantly higher response rate was observed in the CIT combination group (55\%) than in the chemotherapy alone group (29\%), with progression-free survival (PFS) of 13 vs. 6 months, respectively. The magnitude of adverse effects (grade 3 or above) in both the groups was comparable ( 39 vs. $26 \%$, respectively). Based on this study, the FDA granted accelerated approval of pembrolizumab in combination with carboplatin and pemetrexed for the treatment of NSCLC adenocarcinoma in the first-line setting. Updated survival data with median follow-up of 18.7 months showed a PFS of 19.0 months in CIT group vs. 8.9 months in chemotherapy group, with OS in CIT group not reached vs. 20.9 months in the chemotherapy $\operatorname{arm}(32)$.

In KEYONOTE-021 study, the tumor cell-associated PD-L1 expression level can impact the response rates in patients who received CIT treatment: response rate of $57 \%$ in those with $<1 \%$ PD-L1 expression, $54 \%$ in those with $\geq 1 \%$ PD-L1 expression, $26 \%$ in those with $1-49 \%$ PD-L1 expression, and $80 \%$ in those with $\geq 50 \%$ PD-L1 expression (30). Accordingly, higher cutoff of PD-L1 expression was associated with higher response rates. Since pembrolizumab singe-agent is only indicated in NSCLC patients with $\geq 50 \%$ PD-L1 expression in the frontline setting $(33,34)$, this study established CIT as an alternative first-line therapeutic approach for nonsquamous NSCLC patients with $<50 \%$ tumor PD-L1 expression, who do not harbor targetable mutations.

The results of the phase 3 trial (KEYNOTE-189) evaluating pembrolizumab in combination with chemotherapy in frontline setting in nonsquamous NSCLC patients without sensitizing EGFR or ALK mutations have been recently reported. A total of 616 patients were randomized in a 2:1 ratio to receive pemetrexed and platinum-based drug plus either pembrolizumab or placebo for 4 cycles, followed by pembrolizumab or placebo (for up to 35 cycles) plus pemetrexed maintenance therapy. With a median follow-up of 10.5 months, the 12 -month OS was $69.2 \%$ in combination group vs. $49.4 \%$ in placebo group, and median PFS was 8.8 vs. 4.9 months, respectively. Interestingly, the survival benefit was seen across all PD-L1 categories (35). 
A phase 3 trial evaluating CIT combination in frontline setting is currently ongoing for squamous NSCLC (KEYNOTE-407). The results from a second interim analysis after patients had been followed for a median of 7.8 months were recently presented (36). A total of 559 patients were enrolled and stratified prior to randomization based on tumor PD-L1 expression ( $<1$ vs. $\geq 1 \%$ ) as well as the choice of taxane (paclitaxel vs. nab-paclitaxel). Patients were assigned to receive four cycles of carboplatin and paclitaxel/nab-paclitaxel plus either pembrolizumab or placebo, followed by pembrolizumab (for CIT group) or placebo (for placebo group) maintenance therapy. Patients in the placebo group could cross over to receive pembrolizumab monotherapy after disease progression. Significant improvements in OS, PFS, and response rate were observed in CIT group vs. chemo-alone group regardless of PD-L1 expression level: the median OS of 15.9 vs. 11.3 months (HR $0.64,95 \%$ CI $[0.49,0.85] ; p=0.0008)$, PFS of 6.4 vs. 4.8 months (HR $0.56,95 \%$ CI $[0.45,0.70] ; p<0.0001$ ), and objective response rate of 58.4 vs. $35.0 \%$ at the first interim analysis $(p=0.0004)$, respectively.

Nivolumab has also been tested in multiple clinical trials. In phase 1 CHECKMATE-012 trail, 56 patients with NSCLC received first-line therapy with combination of nivolumab with either gemcitabine and cisplatin, pemetrexed and cisplatin, or paclitaxel and carboplatin, followed by nivolumab maintenance therapy (37). CIT combination demonstrated improved ORR compared with nivolumab monotherapy in the front-line setting, with a manageable, non-overlapping toxicity profile. While nivolumab monotherapy has shown an ORR of $23 \%$ in the historical study (38), it demonstrated a higher ORR when combined with gemcitabine and cisplatin (33\%), or pemetrexed and cisplatin $(47 \%)$, or paclitaxel and carboplatin (43\%), with acceptable tolerability and toxicity profiles. In addition to that, association between treatment response and PD-L1 expression levels was not observed (ORR $48 \%$ in PD-L1 $\geq 1$ vs. $43 \%$ in PD-L1 < 1\%).

A phase 3 study (CHECKMATE-227) is ongoing to evaluate nivolumab in combination with chemotherapy vs. chemotherapy alone in the frontline setting for patients with NSCLC (39). A total of 550 chemo-naive NSCLC patients without known sensitizing EGFR/ALK mutations, with $<1 \%$ tumor PD-L1 expression were randomized to receive nivolumab $3 \mathrm{mg} / \mathrm{kg}$ Q2W + ipilimumab $1 \mathrm{mg} / \mathrm{kg}$ Q6W, nivolumab $360 \mathrm{mg}$ Q3W + chemo, or chemotherapy for 2 years. In the recently presented results (40), a total of 177 patients received CIT while 186 received chemotherapy alone. With a minimum follow-up of 11.2 months, an improved PFS was seen in nivolumab-chemo arm vs. chemotherapy alone $\operatorname{arm}(\mathrm{HR}=0.74,95 \%$ CI $[0.58,0.94])$. Part 2 of CheckMate 227 is currently ongoing to evaluate the benefit of nivolumab-chemo combinational irrespective of PD-L1 expression.

The FDA approval of the pembrolizumab-chemotherapy combination in NSCLC has encouraged physicians to investigate various CIT in clinical trials in other types of cancers (Table 1). The combination of pembrolizumab with different chemotherapy regimens is being evaluated in PembroPlus study (NCT02331251) for patients with various types of advanced cancers. Pembrolizumab in addition to cisplatin or capecitabine or 5-Fluorouracil is being investigated in KEYNOTE-062 study (NCT02494583) for patients with advanced gastric cancer.
Atezolizumab, an anti-PD-L1 antibody, has also been evaluated in combination with chemotherapy in the phase 1 GP28328 study (NCT01633970) in multiple tumor types, demonstrating improved ORR of CIT in patients with NSCLC (41). Phase 3 studies are the currently ongoing to determine the clinical benefit of atezolizumab in combination with chemotherapy (IMpower 130, IMpower132). Durvalumab, another anti-PD-L1 antibody, is also being evaluated in a phase 3 clinical trial (POSEIDON), randomizing untreated NSCLC patients to chemotherapy alone or chemotherapy in combination with durvalumab with or without anti-CTLA4 antibody, tremelimumab (NCT03164616).

\section{Considerations and Challenges}

Despite recent clinical success, our limited understanding of the interplay between chemotherapy and immunotherapy hurdles the design of the optimal combination strategy. Different types of chemotherapies execute cytotoxicity against tumors through distinct mechanisms. Similarly, each chemotherapy drug demonstrates unique impact on the systemic and intratumoral immune responses (8). Distinct intrinsic signaling pathways in different types of tumors attribute to the variability in their chemosensitivities. Moreover, the advanced knowledge of immune checkpoint pathways has rapidly expanded the list of ICIs that are acting through different mechanisms (e.g., TIM-3, LAG-3, indoleamine 2,3-dioxygenase, B7-H3). Understanding the impact of chemotherapy in the setting of different types of immunotherapies, as well as the impact of immunotherapy on chemosensitivity (or chemoresistance) of tumors, at both cellular and molecular levels are crucial for the design of rational combination regimens with minimized toxicity.

It is not just the appropriate combination but also the sequence and scheduling of CIT that have to be considered in the clinical scenario. In most of the clinical trials, chemotherapy and immunotherapy are given concurrently, lacking the understanding of the impact of sequencing on the antitumor immunity. Given the fact that antitumor $\mathrm{T}$ cell response has different phases that can be targeted by different ICIs $(47,48)$, and that chemotherapy can modulate immune system while having cytotoxicity against $\mathrm{T}$ cells at the same time, it is very likely that the sequence and timing of CIT would significantly impact the treatment outcomes. Both preclinical and clinical studies have shown controversial results regarding the sequence of CIT, and the ideal combination regimens are evolving. Since chemotherapy can cause immunogenic tumor death that promotes $\mathrm{T}$ cell priming, some have thought that immunotherapy should be given after chemotherapy to allow maximal $\mathrm{T}$ cell proliferation and expansion. In a phase 2 study investigating carboplatin and paclitaxel in combination with concurrent or sequenced ipilimumab in small-cell lung cancer (SCLC), the sequenced treatment is associated with improved PFS compared with chemotherapy alone (49). However, in a mesothelioma mouse model, concurrent treatment with ipilimumab and chemotherapy improved outcomes compared with sequential therapy (50). By contrast, studies in lung cancers and melanoma have shown that chemotherapy administered after immunotherapy can achieve successful clinical responses $(51,52)$. Our group recently demonstrated that in metastatic melanoma patients who had disease progression after anti-PD1 
TABLE 1 | Completed and ongoing clinical trials evaluating chemotherapy in combination with immune checkpoint inhibitors.

\begin{tabular}{|c|c|c|c|}
\hline Trial & Tumor type & Therapy regimes & Endpoints \\
\hline Gadgeel et al. (30) & $\begin{array}{l}\text { NSCLC (KEYNOTE } \\
\text { 021) phase } 1\end{array}$ & $\begin{array}{l}\text { Cohort A: } \\
\text { Pembrolizumab (pembro) + carboplatin and paclitaxel }(\mathrm{CP}) \rightarrow \\
\text { pembro } \\
\text { Cohort B: } \\
\text { Pembro + CP + bevacizumab }(\mathrm{BEV}) \rightarrow \text { pembro + BEV } \\
\text { Cohort C: } \\
\text { Pembro + carboplatin + pemetrexed }(\text { PEM }) \rightarrow \text { pembro + PEM }\end{array}$ & $\begin{array}{l}\text { Overall response rate (ORR): } 52 \% \\
\text { Progression-free survival (PFS): } 10 \text { months } \\
\text { ORR: } 48 \% \\
\text { PFS: NR } \\
\text { ORR: } 48 \% \\
\text { PFS: } 10\end{array}$ \\
\hline $\begin{array}{l}\text { Langer et al. (31) } \\
\text { Borghaei et al. (32) }\end{array}$ & $\begin{array}{l}\text { NSCLC (KEYNOTE } \\
\text { 021) phase } 2\end{array}$ & $\begin{array}{l}\text { Pembro + carboplatin }+ \text { PEM } \rightarrow \text { pembro + PEM } \\
\text { Carboplatin/PEM } \rightarrow \text { PEM }\end{array}$ & $\begin{array}{l}\text { ORR: } 55 \% \\
\text { PFS: } 19 \text { months } \\
\text { ORR } 29 \% \\
\text { PFS: } 8.9 \text { months }\end{array}$ \\
\hline Gandhi et al. (35) & $\begin{array}{l}\text { NSCLC (nonsquamous) } \\
\text { (KEYNOTE-189) }\end{array}$ & $\begin{array}{l}\text { Pembro + platinum }+ \text { PEM } \rightarrow \text { pembro }+ \text { PEM } \\
\text { Placebo + platinum }+ \text { PEM } \rightarrow \text { PEM }\end{array}$ & $\begin{array}{l}\text { OS (12 months): } 69.2 \% \\
\text { PFS: } 8.8 \text { months } \\
\text { OS (12 months): } 49.4 \% \\
\text { PFS: } 4.9 \text { months }\end{array}$ \\
\hline $\begin{array}{l}\text { KEYNOTE-047 } \\
\text { (ongoing) }\end{array}$ & NSCLC (squamous) & $\begin{array}{l}\text { Pembro }+\mathrm{CP} \rightarrow \text { Pembro } \\
\text { Placebo }+\mathrm{CP}\end{array}$ & $\begin{array}{l}\text { Primary: OS and PFS } \\
\text { Secondary: ORR }\end{array}$ \\
\hline Weiss et al. (42) & $\begin{array}{l}\text { Advanced, metastatic } \\
\text { solid tumors } \\
\text { (PEMBRO-PLUS) }\end{array}$ & $\begin{array}{l}\text { Pembrolizumab plus gemcitabine (G), G + docetaxel (D), } \\
G+\text { nab-paclitaxel (NP), G + vinorelbine (V), or irinotecan }\end{array}$ & $\begin{array}{l}\text { Standard dose pembrolizumab can be safely } \\
\text { combined with G, G + NP, G + V, I, and LD }\end{array}$ \\
\hline Rizvi et al. (37) & $\begin{array}{l}\text { NSCLC (CHECKMATE } \\
\text { 012) phase } 1\end{array}$ & $\begin{array}{l}\text { Nivolumab }(\text { Nivo })+\text { gemcitabine }(\text { GEM })+\text { cisplatin }(\mathrm{CIS}) \rightarrow \text { Nivo } \\
\text { Nivo }+ \text { PEM the }+\mathrm{CIS} \rightarrow \text { Nivo } \\
\text { Nivo }(10 \mathrm{mg} / \mathrm{kg})+\mathrm{CP} \rightarrow \text { Nivo } \\
\text { Nivo }(5 \mathrm{mg} / \mathrm{kg})+\mathrm{CP} \rightarrow \text { Nivo }\end{array}$ & $\begin{array}{l}\text { PFS: } 5.7 \text { months } \\
\text { OS: } 11.6 \text { months } \\
\text { PFS: } 6.8 \text { months } \\
\text { OS: } 19.2 \text { months } \\
\text { PFS: } 4.8 \text { months } \\
\text { OS: } 14.9 \text { months } \\
\text { PFS: } 7.1 \text { months } \\
\text { OS: NR }\end{array}$ \\
\hline Paz-Ares et al. (39) & $\begin{array}{l}\text { NSCLC (CHECKMATE } \\
\text { 227) phase } 3 \\
\text { Ongoing }\end{array}$ & $\begin{array}{l}\text { Chemotherapy alone or in combination with Nivo } \\
\text { Squamous: CP } \\
\text { Nonsquamous: PEM + carboplatin (or cisplatin) }\end{array}$ & $\begin{array}{l}\text { Primary: PFS and OS } \\
\text { Secondary: ORR }\end{array}$ \\
\hline Liu et al. (41) & NSCLC & $\begin{array}{l}\text { Atezolizumab }(\text { Atezo })+\mathrm{CP} \rightarrow \text { Atezo } \\
\text { Atezo }+ \text { carboplatin/PEM } \rightarrow \text { Atezo }+ \text { PEM } \\
\text { Atezo }+ \text { carboplatin }+ \text { nab-paclitaxel } \rightarrow \text { Atezo }\end{array}$ & $\begin{array}{l}\text { ORR: } 36 \% \\
\text { PFS: } 7.1 \text { months } \\
\text { OSS: } 12.9 \text { months } \\
\text { ORR: } 68 \% \\
\text { PFS: } 8.4 \text { months } \\
\text { OS: } 18.9 \text { months } \\
\text { ORR: } 46 \% \\
\text { PFS: } 5.7 \text { months } \\
\text { OS: } 17.0 \text { months }\end{array}$ \\
\hline $\begin{array}{l}\text { NCT02367781 } \\
\text { NCT02367794 } \\
\text { NCT02657434 }\end{array}$ & $\begin{array}{l}\text { IMpower } 130 \text { (NSCLC } \\
\text { nonsquamous) } \\
\text { IMpower } 131 \text { (NSCLC } \\
\text { Squamous) } \\
\text { IMpower } 132 \text { (NSCLC } \\
\text { nonsquamous) } \\
\text { All ongoing }\end{array}$ & $\begin{array}{l}\text { Atezo }+ \text { carboplatin }+ \text { nab-paclitaxel } \rightarrow \text { Atezo } \\
\text { Atezo }+ \text { CP } \rightarrow \text { Atezo } \\
\text { Atezo }+ \text { PEM/carboplatin (or cisplatin) } \rightarrow \text { Atezo }+ \text { PEM }\end{array}$ & $\begin{array}{l}\text { Primary: PFS and OS } \\
\text { Secondary: ORR }\end{array}$ \\
\hline NCT02537418 & $\begin{array}{l}\text { NSCLC (PESEIDON) } \\
\text { Phase } 3 \\
\text { Ongoing }\end{array}$ & $\begin{array}{l}\text { Durvalumab + tremelimumab + chemotherapy (histology-based) } \\
\text { Durvalumab + chemotherapy (histology-based) } \\
\text { Chemotherapy (histology-based) }\end{array}$ & Primary: PFS Secondary: OS and ORR \\
\hline NCT02735239 & $\begin{array}{l}\text { Metastatic/locally } \\
\text { advanced esophageal } \\
\text { cancer (neoadjuvant } \\
\text { therapy) }\end{array}$ & $\begin{array}{l}\text { Durvalumab in combination with standard of care chemotherapy } \\
\text { or chemoradiation }\end{array}$ & $\begin{array}{l}\text { Primary: Adverse events, dose-limiting toxicities } \\
\text { Secondary: ORR, PFS, OS }\end{array}$ \\
\hline NCT03317496 & $\begin{array}{l}\text { NSCLC } \\
\text { Urothelial Cancer }\end{array}$ & $\begin{array}{l}\text { Avelumab + pemetrexed/carboplatin } \\
\text { Avelumab + gemcitabine/cisplatin }\end{array}$ & $\begin{array}{l}\text { Primary: Confirmed OR } \\
\text { Secondary: PFS, OS, duration of response, time to } \\
\text { tumor response }\end{array}$ \\
\hline
\end{tabular}


TABLE 1 | Continued

\begin{tabular}{|c|c|c|c|}
\hline Trial & Tumor type & Therapy regimes & Endpoints \\
\hline Govindan et al. (43) & Advanced NSCLC & $\begin{array}{l}\text { Ipilimumab + CP } \\
\text { Placebo + CP }\end{array}$ & $\begin{array}{l}\text { OS: } 13.5 \text { months } \\
\text { PFS: } 5.6 \text { months } \\
\text { (with higher toxicities) } \\
\text { OS: } 12.4 \text { months } \\
\text { PFS: } 5.6 \text { months }\end{array}$ \\
\hline Patel et al. (44) & Metastatic melanoma & Ipilimumab plus temozolomide & $\begin{array}{l}\text { 6-month PFS was } 45 \% \text { with median OS of } \\
24.5 \text { months. } 10 \text { ( } 15.6 \%) \text { confirmed partial responses } \\
\text { and } 10(15.6 \%) \text { confirmed complete responses. No } \\
\text { deaths/unexpected toxicities }\end{array}$ \\
\hline Reck et al. (45) & SCLC & $\begin{array}{l}\text { Ipilimumab + etoposide and platinum } \\
\text { Placebo + etoposide and platinum }\end{array}$ & $\begin{array}{l}\text { OS: } 11.0 \text { months } \\
\text { PFS: } 4.6 \text { months } \\
\text { OS: } 10.9 \text { months } \\
\text { PFS: } 4.4 \text { months }\end{array}$ \\
\hline Yamazaki et al. (46) & Melanoma & Ipilimumab + dacarbazine & $\begin{array}{l}\text { Was not considered tolerable in the Japanese patient } \\
\text { population }\end{array}$ \\
\hline
\end{tabular}

monotherapy, the addition of chemotherapy to PD-1 blockade induced a significantly improved clinical response, with an ORR of $65 \%$ (CR of 25\%) (53-55). Using peripheral blood from patients who benefited from the CIT combination, we identified a novel subset of therapy-responsive $\mathrm{CD}^{+} \mathrm{T}$ cells $\left(\mathrm{CX} 3 \mathrm{CR} 1^{+}\right)$ that can survive chemotherapy toxicity with preserved CTL functions (53). This subset of effector T cells is less actively proliferating during the combination therapy, and hence is spared from chemocytotoxicity. In addition, these $\mathrm{CX} 3 \mathrm{CR} 1^{+} \mathrm{CD} 8^{+}$ $\mathrm{T}$ cells demonstrate the ability to efflux chemotherapy drugs. Our preclinical animal model studies also demonstrate that that CIT combination after previous exposure to immunotherapy provides better tumor control with an increase in $\mathrm{CX} 3 \mathrm{CR} 1^{+} \mathrm{CD} 8^{+}$ $\mathrm{T}$ cells population (53). Our results elucidated mechanisms that are responsible for the success of combination, facilitating the rational design of CIT. This subset of $\mathrm{T}$ cells may be used as a biomarker in monitoring and predicting clinical response to CIT, especially when tumor PD-L1 levels fail to show direct correlation with the CIT treatment outcomes in multiple clinical trials. Future studies are warranted to define whether the efficacy of CIT is dependent on certain ICI to recruit immune cells into tumor tissues (like CX3CR $1^{+} \mathrm{CD} 8$ effector $\mathrm{T}$ cells) or to expand local tumor-infiltrating immune cells to reject tumors.

The scheduling and timing of chemotherapy in CIT are also critical for achieving clinical success. The fluctuation of dynamic systemic immunity in metastatic melanoma patients has been reported. Chemotherapy that was delivered in synchronization with unique phase of dynamic immune response tends to correlate with improved response (56). Some chemotherapy drugs work in cell cycle specific manners (e.g., S phase for drugs inhibiting DNA synthesis), suggesting that their direct tumor-killing activities and immunomodulatory effects can be influenced by the schedule of drug administrations. Platinum-based chemotherapy given in different dosing schedules has shown different antitumor immune responses associated with variable clinical outcomes in an ovarian cancer mouse model (57). Our recent preclinical study further demonstrated that the timing of chemotherapy administration after the immunotherapy initiation can affect the frequencies of $\mathrm{CX} 3 \mathrm{CR} 1^{+} \mathrm{T}$ cell population and the treatment outcomes (53), suggesting the variable chemo-induced immunomodulation in relationship to the timing of the immunotherapy. With the overwhelming possibility of CIT combinations, further preclinical and clinical research is in need to design rational combinations for different types of cancers, while minimizing the therapeutic toxicities.

\section{COMBINATION OF IMMUNOTHERAPY AND MOLECULAR TARGETED THERAPY}

The identification of deregulated cellular signaling pathways that are responsible for tumorigenesis has led to the successful development of molecular targeted therapy in recent decades. Medications inhibiting oncogenic pathways, DNA repair response, and angiogenesis pathways have provided effective treatment options for patients with different types of malignancies, although response durability is often lacking. Recent research has demonstrated that these pathways also have immunomodulatory effects on systemic and intratumoral antitumor immune responses, suggesting that the combination of molecular targeted therapy with ICIs can result in synergistic antitumor effects.

\section{BRAF and MEK Inhibitors}

Dysregulations in the RAS/RAF/MAPK pathway are commonly seen in oncogenic transformation and tumorigenesis. Mutations in $B R A F$, a proto-oncogene, are associated with various types of cancers, especially melanoma. In patients with BRAF mutant metastatic melanoma, high response rates are observed after treatment with BRAF/MEK inhibitors, although the duration of response is short lasting due to adaptive therapy resistance. Since ICIs provide durable clinical benefit, combinations of ICIs with BRAF/MEK inhibitors may provide fast and long-lasting disease control.

In melanoma cell models, BRAFV600 mutations can lead to decreased antitumor immunity through upregulation of immunosuppressive factors [e.g., IL-10, vascular endothelial growth factor (VEGF)] (58), elevation of PD-L1 expression levels (59), increased tumor infiltration of immunosuppressive cells 
(e.g., Treg) (60), and downregulation of melanoma MHC-1 expression (61). In patients with metastatic melanoma, BRAF inhibitors have shown to decrease the immunosuppressive cytokines with resultant increased $\mathrm{CD} 8^{+} \mathrm{T}$ cell tumor infiltration and antitumor immunity (62). In addition, the treatment response of BRAF inhibitors is $\mathrm{CD}^{+} \mathrm{T}$-cell dependent $(60,63)$. Interestingly, in CRC patients, the majority of those who have PD-L1 positive tumor carry BRAF mutations along with microsatellite instability, suggesting that the immunosuppressive tumor microenvironment can be induced by BRAF mutations (64). In a colorectal carcinoma mouse model, MEK inhibitors demonstrated synergistic therapeutic effects with anti-PD-L1 antibody (65). In a melanoma mouse model, dabrafenib treatment alone results in increased TAMs and Treg, while the addition of trametinib further decreases these suppressive cell subsets. When combined with anti-PD-L1 antibody, the triple therapy provides a superior tumor control (66).

The combination of BRAF inhibitors with anti-CTLA-4 antibody has been studied in multiple clinical trials. However, substantial immune-related adverse effects were the main concern in several studies. Liver toxicity and high-grade skin adverse effects were seen in trials with vemurafenib and ipilimumab combination (NCT01400451 and NCT01673854) $(67,68)$. Severe colitis was seen in patients who received dabrafenib, trametinib, and ipilimumab triple combination (NCT01767454). Anti-PD1/ PD-L1 antibodies were also evaluated in combination with BRAF/MEK inhibitors (Table 2). In a phase 1 study, the combination of dabrafenib, trametinib, and durvalumab demonstrated tolerable toxicity profiles and encouraging disease response rates (69). Pembrolizumab is also being studied in combination with dabrafenib and trametinib in patients with metastatic melanoma (NCT02130466). Multiple other clinical trials are currently ongoing (NCT01940809; NCT01656642; NCT02027961; NCT0$2224781)$ to test similar combinations.

Combining BRAF/MEK inhibitors with ICIs has the potential to overcome resistance to targeted therapy; however, further investigations are needed to understand the underlying molecular interplay and to design the ideal combination regimens. Given the toxicities observed in early trials, the optimum tolerable dose of targeted therapy in combination with ICIs needs to be determined. The rapid development of resistance to BRAF/MEK inhibitors and their dynamic impacts on the tumor microenvironment and systemic antitumor immunity should also be considered to determine the sequencing and scheduling of the combination. One study demonstrated long-term tumor control after short-term targeted therapy with subsequent anti-PD1 antibody in patients with metastatic melanoma, and $\mathrm{T}$ cell tumor infiltration was seen in tumor biopsies within 1 week after BRAF/MEK inhibitors administration while less frequent after 2 weeks on therapy (71), suggesting that the timing of combination with PD-1 blockade can impact patient outcomes.

Other oncogenic pathways, such as PI3K-Akt-mTOR pathway and KIT, can also regulate the antitumor immunity in addition to regulating cellular proliferation, providing further options for combination therapy with ICIs. For example, inhibition of PI3k $\gamma$ can promote $\mathrm{T}$ cell infiltration through regulating the balance between stimulatory and suppressive TAMs (72). Inhibition of KIT decreased the INF- $\gamma$ induced PD-L1 expression (73). Treatments targeting these pathways are also being investigated in combination with ICIs to overcome their limited clinical response. The crosstalk between multiple signaling oncogenic pathways in the setting of immunotherapy should be further investigated to determine the ideal drugs to be combined, with special consideration of the individual's unique intrinsic genetic background.

\section{Poly (ADP-Ribose) Polymerase (PARP) Inhibitors}

DNA damage repair machinery plays important roles in cell cycle regulation and tumorigenesis (74). Inhibition of DNA damage repair can potentially increase the tumor mutational burden, especially in tumors with high endogenous DNA damage. PARP plays a critical role in the repair of single-strand DNA break. In tumor cells with BRCA mutations, PARP inhibition can increase the genomic instability and cell death, with resultant increased neoantigen load and antitumor $\mathrm{T}$ cell response (75). This synthetic lethality of PARP inhibitors established the foundation for its clinical application in cancer treatment (76). PARP inhibitors also demonstrate immunoregulatory effects in preclinical studies. They can attenuate chronic inflammation and increase $\mathrm{T}$ cell infiltration (77).

Olaparib has been recently approved for the treatment of ovarian cancers with BRCA1 and BRCA2 mutations. Olaparib in combination with PD-L1 inhibitor, durvalumab, was recently investigated in a clinical trial for patients with gynecologic

TABLE 2 | Clinical trials of BRAF targeted therapy in combination with immune checkpoint inhibitors.

\begin{tabular}{|c|c|c|c|}
\hline Trial & Mutation status & Therapy regimens & Outcomes \\
\hline Puzanov et al. (70) & BRAF V600 mutant melanoma & Dabrafenib \pm trametinib + ipilimumab & Triple therapy resulted in severe GI toxicities \\
\hline Ribas et al. (67) & BRAF V600 mutant melanoma & Vemurafenib + ipilimumab & Combination resulted in severe liver toxicities \\
\hline Ribas et al. (69) & $\begin{array}{l}\text { Both wild-type and BRAF mutant } \\
\text { melanoma }\end{array}$ & $\begin{array}{l}\text { Durvalumab + dabrafenib + trametinib } \\
\text { Durvalumab + trametinib } \\
\text { Trametinib } \rightarrow \text { durvalumab }\end{array}$ & Tolerable, no unexpected toxicity \\
\hline Amin et al. (68) & BRAF V600 mutant melanoma & Vemurafenib + ipilimumab & $\begin{array}{l}\text { Combination resulted in high-grade Gl and skin } \\
\text { toxicities }\end{array}$ \\
\hline NCT02224781 & Metastatic melanoma & $\begin{array}{l}\text { Dabrafenib + trametinib followed by } \\
\text { ipilimumab + nivolumab at progression } \\
\text { vs. ipilimumab + nivolumab followed by } \\
\text { dabrafenib + trametinib }\end{array}$ & $\begin{array}{l}\text { Ongoing } \\
\text { Primary: OS } \\
\text { Secondary: PFS }\end{array}$ \\
\hline
\end{tabular}


cancers. Among 26 enrolled women, a disease control rate of $83 \%$ was reported, with an acceptable safety profile (78). Several trials evaluating different PARP inhibitors in combination with ICIs are currently ongoing in various solid tumors, including NSCLC and breast cancer (Table 3). The combination of niraparib with pembrolizumab was studied in the phase $1 / 2$ TOPACIO/Keynote-162 (NCT02657889) study, and the results from the recurrent ovarian cancer cohort were recently reported (79). Among the 60 evaluable patients, an ORR of $25 \%$ was seen in all platinum-resistant ovarian cancer patients with an ORR of $45 \%$ in those with BRCA mutations. No new safety concerns were identified.

Given the fact that DNA repair response not only regulates tumorigenesis but also plays role in antitumor immunity, it is imperative to fully understand the interplay between DNA repair inhibitors and ICIs to combine them in a safe and effective manner, since inhibition of DNA repair response can potentially decrease the immune response. Moreover, the intrinsic tumor genetic background and DNA repair response status [e.g., BRCA mutation vs. wild-type (WT)] have positive impact on the PARP inhibitor-induced antitumor immune response during immunotherapy. Furthermore, it is possible that different PARP inhibitors can modulate the antitumor immune response through different mechanisms, which could impact the treatment outcomes when combined with different ICIs.

\section{VEGF Inhibitors}

Vascular endothelial growth factor stimulates angiogenesis, tissue remodeling, and fibrosis. Its immunosuppressive effects make VEGF a good target candidate to potentiate the antitumor immune response in combination with ICIs $(80,81)$. Studies from our group have shown that in patients with stage IV melanoma the baseline Treg concentration positively correlates with baseline VEGF level, which associates with poor clinical outcomes (82). Upregulated VEGF level and chronically Th-2-mediated immune status are observed in patients with metastatic melanoma (83).
Animal models have shown that anti-VEGF antibody can increase $\mathrm{T}$ cell tumor infiltration with enhanced antitumor response (84). Decreased Treg proliferation and MDSC population are associated with bevacizumab treatment in CRC (85). The hypoxic conditions resulting from anti-VEGF treatment also can upregulate PD-L1 expression.

Tremelimumab in combination with sunitinib has been evaluated in patients with metastatic melanoma. Unfortunately, unexpected dose-limiting renal toxicity was observed (86). High dose of tremelimumab $(6 \mathrm{mg} / \mathrm{kg})$ used in this study could contribute to the adverse effects. Bevacizumab was also investigated in combination with ipilimumab in melanoma patients (87). A disease control rate of $67.4 \%$ was observed with combination therapy, with increased $\mathrm{CD}^{+}$lymphocyte infiltration resulting from more effective lymphocytic trafficking. Multiple clinical trials are currently ongoing investigating the combination of bevacizumab and pembrolizumab in patients with ovarian cancer (NCT02853318) and solid tumor brain metastases (NCT02681549). Other agents targeting VEGF pathway, such as ramucirumab, are also being evaluated in combination regimens (Table 3). Lenvatinib, a tyrosine kinase inhibitor, is being studied in combination with pembrolizumab in a phase $1 / 2$ trial (NCT03006926). However, the dynamic immunologic effects of these combinations remain to be elucidated. In a recent report, 10 patients with metastatic renal cell carcinoma were treated with bevacizumab plus atezolizumab after bevacizumab run-in period (88). A partial disease response was observed in four patients, and median time to response was 4.2 months. Following combination therapy, increased intratumoral $\mathrm{CD}^{+} \mathrm{T}$ cells, Th1, and $\mathrm{T}$ effector markers are found. Interestingly, increases in intratumoral chemokine, CX3CL1, and peripheral CX3CR1 ${ }^{+}$(CX3CL1 receptor) $\mathrm{CD}^{+} \mathrm{T}$ cells are observed after combination therapy, similar to the observation in patients received CIT combination (53). Clinical trials are ongoing to evaluate this combination in untreated metastatic renal cell carcinoma (IMmotion151 study)

TABLE 3 | Clinical trials of immune checkpoint inhibitors in combination with poly (ADP-ribose) polymerase inhibitors or vascular endothelial growth factor targeting therapy.

\begin{tabular}{|c|c|c|c|}
\hline Trial & Tumor type & Treatment regimen & Outcome \\
\hline Lee et al. (78) & Gynecological cancers & $\begin{array}{l}\text { Durvalumab + olaparib } \\
\text { Durvalumab + cediranib }\end{array}$ & $\begin{array}{l}83 \% \text { disease control rate in } \\
\text { durvalumab + olaparib group } \\
75 \% \text { disease control rate in } \\
\text { durvalumab plus cediranib group }\end{array}$ \\
\hline NCT02734004 & Breast, gastric, ovarian and SCLC & Durvalumab + olaparib & Ongoing \\
\hline NCT02484404 & NSCLC, SCLC, breast, ovarian, colorectal, prostate & $\begin{array}{l}\text { Durvalumab + olaparib } \\
\text { Durvalumab + cediranib } \\
\text { Durvalumab + olaparib + cediranib }\end{array}$ & Ongoing \\
\hline NCT02657889 & Breast and ovarian & Pembrolizumab + niraparib & Ongoing \\
\hline NCT02944396 & NSCLC & $\begin{array}{l}\text { Nivolumab + veliparib + platinum-based chemotherapy } \\
\text { Veliparib + platinum-based chemotherapy }\end{array}$ & Ongoing \\
\hline NCT02849496 & Breast & $\begin{array}{l}\text { Veliparib } \\
\text { Atezolizumab } \\
\text { Veliparib + atezolizumab }\end{array}$ & Ongoing \\
\hline NCT02443324 & $\begin{array}{l}\text { Gastric, GEJ adenocarcinoma, NSCLC, transitional } \\
\text { cell carcinoma of the urothelium, biliary tract }\end{array}$ & Pembrolizumab + ramucirumab & Ongoing \\
\hline NCT02572687 & Gl or thoracic malignancies & Durvalumab + ramucirumab & Ongoing \\
\hline
\end{tabular}


(89) and untreated locally advanced or metastatic hepatocellular carcinoma (IMbrave150) (NCT03434379). Further investigation will be critical to design safe and efficacious combinations and to address biomarker selection.

\section{COMBINATION OF IMMUNOTHERAPY WITH RADIOTHERAPY (RT)}

Radiotherapy remains to be the backbone modality in the treatment for different types of cancer, either given alone or in combination with chemotherapy. It induces single- and double-strand DNA breaks, triggering multiple signaling pathways including DNA damage responses and activation of cell cycle checkpoints. The RT-induced cell death can further initiate systemic antitumor responses through various immune cell subsets (90). The participation of immune cells is indispensable for the clinical benefit of RT; in turn, RT can also modulate the antitumor immunity. It has been reported that localized tumor radiation can result in distant systemic tumor control in the unirradiated area. This clinical phenomenon, known as the abscopal effect, is a result of RT-induced immune modulations (91). The potential synergistic antitumor activities of RT in combination with ICIs have attracted increased research efforts in this new era of cancer immunotherapy (92).

Increased infiltration of macrophages and monocytes has been observed post-irradiation in multiple humana cancer xenograft models (squamous cell carcinoma, breast, and lung carcinoma), and depletion of the TAMs with antibody to CD11b or inhibitor of SDF-1a receptor CXCR4 (AMD3100) provided further tumor control when combined with irradiation $(93,94)$. The activation of dendritic cells and their release of type I interferon after irradiation is also critical in $\mathrm{CD}^{+} \mathrm{T}$ cell activity and treatment efficacy in mouse colon carcinoma (MC38), lung carcinoma (LLC), and melanoma models (B16F10) $(95,96)$. In an animal model of Lewis lung carcinoma (LLC), when the local area was exposed to irradiation, distant tumor control was observed only in p53 WT (vs. in p53 null mice), suggesting that the abscopal effect was mediated through pathways downstream of p53 (97). Multiple studies have shown that cytotoxic $\mathrm{CD}^{+} \mathrm{T}$ cells are required for RT-induced tumor control in mouse breast cancer (4T1), melanoma (B16), lymphoma (EL4), and lung cancer $(98,99)$.

Although the myelosuppression after irradiation is thought to be immunosuppressive, $\mathrm{RT}$ can regulate $\mathrm{T}$ cell-mediated immune responses via various mechanisms (100). RT regulates key cell surface molecules for cytotoxic immune cell activation (NKG2D), and antigen presentation machinery (MHC class I expression with antigen peptides), therefore augments $\mathrm{T}$ cell tumor recognition and activation $(101,102)$. RT also enhances $\mathrm{T}$ cell priming for activation via activation of antigen-presenting cells (dendritic cells) and releasing of immunogenic antigens $(95,103)$. RT increases the release of chemokines (CXCL16, a chemokine that binds to CXCR6 on Th1 CD4 and effector CD8 $\mathrm{T}$ cells) by mouse breast cancer (4T1) cells, therefore enhances the infiltration of cytotoxic T cells (104). In this situation, blockade of CTLA-4 further promotes tumor regression. Irradiation also alters the immunosuppressive tumor microenvironment to a $\mathrm{M} 1$ phenotype, favoring accessibility for $\mathrm{T}$ cell infiltration
(105). In addition, in melanoma and Kras-mutant lung cancer models, irradiation was found to upregulate PD-L1 expression in tumor microenvironment $(106,107)$. The synergistic relationship between RT and ICI has been further explored in preclinical models. In mice bearing poorly immunogenic breast carcinoma, treatment with CTLA-4 blockade in combination with RT (vs. CTLA-4 blockade alone) resulted in decreased tumor growth and metastasis with improved survival (108). RT in combination with PD-1 blockade also induced improved and durable tumor control in NSCLC mouse models (107). In melanoma and renal cell carcinoma animal models, $\mathrm{PD}-1$ knockout $(\mathrm{KO})$ mice demonstrated higher survival after stereotactic ablative radiotherapy (SABR) compared with their PD-1 WT little mates. The addition of PD-1 blocking antibody to SABR led to the improved antitumor response and survival in $\mathrm{PD}-1 \mathrm{WT}$ mice. In addition, treatment with SABR and anti-PD1 antibody combination induced significant reduction of non-irradiate tumor. The increased frequency of $\mathrm{CD}_{11} \mathrm{a}^{\text {high }} \mathrm{CD}^{+}$tumor-reactive $\mathrm{T}$ cells and their enhanced functions were associated with the antitumor response in PD-1 $\mathrm{KO}$ mice, suggesting the translation potential of combining RT and PD-1 blockade (109).

Over the recent years, the clinical efficacy of RT in combination with ICIs have been studied in multiple clinical trials were designed to investigate. However, data supporting the routine application of this combination are still limited. The RT and ipilimumab combination demonstrated acceptable toxicity profile in patients with metastatic melanoma, yet failed to provide survival benefit (110). Ipilimumab in combination with radiation was evaluated in a single-arm phase 2 study in melanoma patients with unresectable brain metastases (111). Fifty-eight patients were enrolled in this study; with 1-year OS of $31.8 \%$ (95\% CI [18.8-44.8\%]) that is higher than the historical reported results, without unexpected adverse events.

In a phase 1 KEYNOTE-001 study, 97 patients with advanced NSCLC were enrolled (112). Longer PFS and OS, without higher incidence of grade 3 or above pulmonary toxicity, were seen in patients who underwent RT prior to anti-PD1 therapy compared with those who did not receive RT, supporting the safety and potential synergistic activity of the RT-ICI combination. The phase 3 randomized PACIFIC trial investigated the role of subsequent durvalumab therapy in stage III NSCLC patients after definitive chemoradiation (NCT02125461) (113). A total of 713 patients with locally advanced unresectable NSCLC without disease progression after definitive chemoradiation were randomly assigned in 2:1 to receive durvalumab or placebo irrespective of PD-L1 status. Median progression survival is 16.8 months in durvalumab group vs. 5.6 months in placebo group (16.8 months vs.), with 18 -month PFS rate of 44.2 vs. $27.0 \%$, respectively (113). Results from this study led to the FDA approval of durvalumab for the treatment of stage III NSCLC regardless of PD-L1 expression levels. The RT and immunotherapy combination is currently being evaluated in other tumor types, such as metastatic GI malignancies (NCT02830594) and metastatic breast cancer (NCT02730130) (Table 4).

Despite the encouraging finding from the PACIFIC trial, future research is urgently needed to define the immunoregulatory mechanisms that cross talk between RT, chemo, and immunotherapy, to design optimized combination strategies. Similar to 
TABLE 4 | Clinical trials of immune checkpoint inhibitors in combination with radiotherapy (RT).

\begin{tabular}{|c|c|c|c|}
\hline Trial & Tumor type & Regimens & Outcomes \\
\hline $\begin{array}{l}\text { Shaverdian } \\
\text { et al. (112) }\end{array}$ & $\begin{array}{l}\text { NSCLC } \\
\text { (KEYNOTE-001) }\end{array}$ & $\begin{array}{l}\text { Compared patients on pembrolizumab with previous RT } \\
\text { to those who did not receive previous RT }\end{array}$ & $\begin{array}{l}\text { Previous treatment with RT results in longer PFS and OS, with } \\
\text { an acceptable safety profile }\end{array}$ \\
\hline Antonia et al. (113) & NSCLC & $\begin{array}{l}\text { Definitive ChemoRT } \rightarrow \text { durvalumab } \\
\text { Definitive ChemoRT } \rightarrow \text { placebo }\end{array}$ & $\begin{array}{l}\text { Progression-free survival (PFS): } 16.8 \text { months } \\
18 \text { months PFS: } 44.2 \% \\
\text { PFS: } 5.6 \text { months } \\
18 \text { months PFS: } 27.0 \%\end{array}$ \\
\hline Levy et al. (114) & $\begin{array}{l}\text { Inoperable or } \\
\text { metastatic cancers }\end{array}$ & Concurrent durvalumab + RT & $\begin{array}{l}\text { Concurrent palliative RT with the anti-PD-L1 durvalumab was } \\
\text { well tolerated }\end{array}$ \\
\hline Tang et al. (115) & $\begin{array}{l}\text { Metastatic solid } \\
\text { tumor }\end{array}$ & $\begin{array}{l}\text { Ipilimumab + stereotactic ablative radiotherapy } \\
\text { (SABR) }\end{array}$ & $\begin{array}{l}\text { Combining SABR and ipilimumab was safe with signs of } \\
\text { efficacy, peripheral T-cell markers may predict clinical benefit, } \\
\text { and systemic immune activation was greater after liver irradiation }\end{array}$ \\
\hline Hiniker et al. (116) & Metastatic melanoma & Palliative RT + ipilimumab & $\begin{array}{l}\text { Combination therapy was well tolerated without unexpected } \\
\text { toxicities. Eleven patients ( } 50.0 \% \text { ) experienced clinical benefit from } \\
\text { therapy, including complete and partial responses }\end{array}$ \\
\hline NCT03050554 & NSCLC & $\begin{array}{l}\text { Stereotactic body radiation therapy (SBRT) in } \\
\text { combination with Avelumab }\end{array}$ & $\begin{array}{l}\text { Ongoing } \\
\text { Tolerability, RFS }\end{array}$ \\
\hline NCT02658097 & NSCLC & $\begin{array}{l}\text { Single fraction nonablative radiation in combination with } \\
\text { pembrolizumab }\end{array}$ & $\begin{array}{l}\text { Ongoing } \\
\text { RR and best OS }\end{array}$ \\
\hline NCT03458455 & Brain tumor & $\begin{array}{l}\text { Stereotactic radiosurgery plus ipilimumab, nivolumab, or } \\
\text { pembrolizumab }\end{array}$ & $\begin{array}{l}\text { Ongoing } \\
\text { Treatment response at } 18 \text { months }\end{array}$ \\
\hline NCT03115801 & $\begin{array}{l}\text { Metastatic renal } \\
\text { cell carcinoma and } \\
\text { urothelial carcinoma }\end{array}$ & $\begin{array}{l}\text { Nivolumab/atezolizumab } \\
\text { Nivolumab/atezolizumab plus RT }\end{array}$ & $\begin{array}{l}\text { Ongoing } \\
\text { Best overall response rate, PFS, toxicities, OS }\end{array}$ \\
\hline NCT03176173 & NSCLC & $\begin{array}{l}\text { Radical-dose image guided radiation therapy daily for up } \\
\text { to } 10 \text { days (within } 2 \text { weeks) while undergoing standard of } \\
\text { care immunotherapy } \\
\text { Patients who decline to undergo radiation therapy receive } \\
\text { standard of care immunotherapy }\end{array}$ & $\begin{array}{l}\text { Ongoing } \\
\text { PFS }\end{array}$ \\
\hline
\end{tabular}

other combination strategies discussed, the optimum sequencing of the RT and ICI combination has not been elucidated in available studies. In the KEYNOTE-001 study, irradiation prior to pembrolizumab therapy provided improved PFS and OS (112), while in another clinical report palliative RT-induced global disease control in a PD-1 antibody resistant patient (117). In a melanoma mouse model, the addition of adjuvant chemotherapy after ablative RT abrogated the RT-induced $\mathrm{CD} 8^{+} \mathrm{T}$ cell activation and tumor control, while the addition of immunotherapy can enhance the tumor response (98), suggesting that the treatment modalities and the sequence of their combination need to be carefully investigated to achieve clinical success. In addition, research is needed to identify biomarkers with both predictive and prognostic values in RT-immunotherapy combination.

\section{CONCLUSION}

Modern cancer immunotherapies exert their tumor-killing activities through enhancing antitumor immunity while suppressing the tumor-promoting immune process. However, since ICIs do not provide clinical benefits in the majority of cancer patients, it is crucial to design rational and efficacious synergic therapeutic approaches to increase clinical responses to ICI. The combination of chemotherapy, targeted therapy, and RT with ICIs has gained increased attentions from clinicians and researchers over the recent years, given their immunomodulatory effects and potential synergistic antitumor activities. Despite the encouraging clinical results from various clinical studies, further investigations are warranted to elucidate the exact molecular and cellular mechanisms driving these clinical responses. More importantly, the optimal regimens, dose, timing, and schedule of the combination therapy for differently types of tumors are yet to be identified. Molecular interplay between different therapeutic modalities will need to be further investigated given the unlimited possibilities of combining currently available cancer treatments.

\section{AUTHOR CONTRIBUTIONS}

YY and HD conceived the outline of the manuscript. YY, HD, AK, $\mathrm{HF}$, and SM wrote and edited the manuscript. SP and RD edited the manuscript.

\section{FUNDING}

This research is funded by Mayo Clinic Internal Funding. NCI R21 CA197878 (HD and RD), NCI R01 CA200551 (SP and HD), NIAID R01 AI095239 (HD), NCI K12 CA090628 (YY), NIH T32 GM008685-20 (AK). 


\section{REFERENCES}

1. Topalian SL, Hodi FS, Brahmer JR, Gettinger SN, Smith DC, McDermott DF, et al. Safety, activity, and immune correlates of anti-PD-1 antibody in cancer. N Engl J Med (2012) 366(26):2443-54. doi:10.1056/NEJMoa1200690

2. Topalian SL, Sznol M, McDermott DF, Kluger HM, Carvajal RD, Sharfman WH, et al. Survival, durable tumor remission, and long-term safety in patients with advanced melanoma receiving nivolumab. J Clin Oncol (2014) 32(10):1020-30. doi:10.1200/JCO.2013.53.0105

3. Rexer H, Bedke J. [First-line therapy in advanced renal cell carcinoma: a randomized, open-label phase III study evaluating the efficacy and safety of pembrolizumab (MK-3475) in combination with axitinib compared to sunitinib monotherapy as first-line treatment for locally advanced or metastatic renal cell carcinoma (mRCC) (Keynote-426) - AN 39/16 of the AUO]. Urologe A (2017) 56(3):385-6. doi:10.1007/s00120-017-0335-2

4. Larkins E, Blumenthal GM, Yuan W, He K, Sridhara R, Subramaniam S, et al. FDA approval summary: pembrolizumab for the treatment of recurrent or metastatic head and neck squamous cell carcinoma with disease progression on or after platinum-containing chemotherapy. Oncologist (2017) 22(7):873-8. doi:10.1634/theoncologist.2016-0496

5. Pardoll DM. The blockade of immune checkpoints in cancer immunotherapy. Nat Rev Cancer (2012) 12(4):252-64. doi:10.1038/nrc3239

6. Robert C, Schachter J, Long GV, Arance A, Grob JJ, Mortier L, et al. Pembrolizumab versus ipilimumab in advanced melanoma. $N$ Engl J Med (2015) 372(26):2521-32. doi:10.1056/NEJMoa1503093

7. Larkin J, Hodi FS, Wolchok JD. Combined nivolumab and ipilimumab or monotherapy in untreated melanoma. N Engl J Med (2015) 373(13):1270-1. doi:10.1056/NEJMc1509660

8. Coffelt SB, de Visser KE. Immune-mediated mechanisms influencing the efficacy of anticancer therapies. Trends Immunol (2015) 36(4):198-216. doi:10.1016/j.it.2015.02.006

9. Galluzzi L, Buque A, Kepp O, Zitvogel L, Kroemer G. Immunological effects of conventional chemotherapy and targeted anticancer agents. Cancer Cell (2015) 28(6):690-714. doi:10.1016/j.ccell.2015.10.012

10. Apetoh L, Ladoire S, Coukos G, Ghiringhelli F. Combining immunotherapy and anticancer agents: the right path to achieve cancer cure? Ann Oncol (2015) 26(9):1813-23. doi:10.1093/annonc/mdv209

11. Zitvogel L, Galluzzi L, Smyth MJ, Kroemer G. Mechanism of action of conventional and targeted anticancer therapies: reinstating immunosurveillance. Immunity (2013) 39(1):74-88. doi:10.1016/j.immuni.2013.06.014

12. Gotwals P, Cameron S, Cipolletta D, Cremasco V, Crystal A, Hewes B, et al. Prospects for combining targeted and conventional cancer therapy with immunotherapy. Nat Rev Cancer (2017) 17(5):286-301. doi:10.1038/nrc. 2017.17

13. DeVita VT Jr, Chu E. A history of cancer chemotherapy. Cancer Res (2008) 68(21):8643-53. doi:10.1158/0008-5472.CAN-07-6611

14. Bezu L, Gomes-de-Silva LC, Dewitte H, Breckpot K, Fucikova J, Spisek R, et al. Combinatorial strategies for the induction of immunogenic cell death. Front Immunol (2015) 6:187. doi:10.3389/fimmu.2015.00187

15. Rizvi NA, Hellmann MD, Snyder A, Kvistborg P, Makarov V, Havel JJ, et al. Cancer immunology. Mutational landscape determines sensitivity to PD-1 blockade in non-small cell lung cancer. Science (2015) 348(6230):124-8. doi:10.1126/science.aaa1348

16. Sistigu A, Yamazaki T, Vacchelli E, Chaba K, Enot DP, Adam J, et al. Cancer cell-autonomous contribution of type I interferon signaling to the efficacy of chemotherapy. Nat Med (2014) 20(11):1301-9. doi:10.1038/ nm.3708

17. Liu WM, Fowler DW, Smith P, Dalgleish AG. Pre-treatment with chemotherapy can enhance the antigenicity and immunogenicity of tumours by promoting adaptive immune responses. Br J Cancer (2010) 102(1):115-23. doi:10.1038/sj.bjc.6605465

18. Ruffell B, Chang-Strachan D, Chan V, Rosenbusch A, Ho CM, Pryer N, et al. Macrophage IL-10 blocks CD8+ T cell-dependent responses to chemotherapy by suppressing IL-12 expression in intratumoral dendritic cells. Cancer Cell (2014) 26(5):623-37. doi:10.1016/j.ccell.2014.09.006

19. Peng J, Hamanishi J, Matsumura N, Abiko K, Murat K, Baba T, et al. Chemotherapy induces programmed cell death-ligand 1 overexpression via the nuclear factor-kappaB to foster an immunosuppressive tumor microenvironment in ovarian cancer. Cancer Res (2015) 75(23):5034-45. doi:10.1158/0008-5472.CAN-14-3098

20. Bunt SK, Yang L, Sinha P, Clements VK, Leips J, Ostrand-Rosenberg S. Reduced inflammation in the tumor microenvironment delays the accumulation of myeloid-derived suppressor cells and limits tumor progression. Cancer Res (2007) 67(20):10019-26. doi:10.1158/0008-5472.CAN-07-2354

21. Gabrilovich DI, Nagaraj S. Myeloid-derived suppressor cells as regulators of the immune system. Nat Rev Immunol (2009) 9(3):162-74. doi:10.1038/ nri2506

22. Baba J, Watanabe S, Saida Y, Tanaka T, Miyabayashi T, Koshio J, et al. Depletion of radio-resistant regulatory $\mathrm{T}$ cells enhances antitumor immunity during recovery from lymphopenia. Blood (2012) 120(12):2417-27. doi:10.1182/ blood-2012-02-411124

23. Nakasone ES, Askautrud HA, Kees T, Park JH, Plaks V, Ewald AJ, et al. Imaging tumor-stroma interactions during chemotherapy reveals contributions of the microenvironment to resistance. Cancer Cell (2012) 21(4): 488-503. doi:10.1016/j.ccr.2012.02.017

24. Ghiringhelli F, Larmonier N, Schmitt E, Parcellier A, Cathelin D, Garrido C, et al. CD4+CD25+ regulatory $\mathrm{T}$ cells suppress tumor immunity but are sensitive to cyclophosphamide which allows immunotherapy of established tumors to be curative. Eur J Immunol (2004) 34(2):336-44. doi:10.1002/ eji.200324181

25. Alizadeh D, Trad M, Hanke NT, Larmonier CB, Janikashvili N, Bonnotte B, et al. Doxorubicin eliminates myeloid-derived suppressor cells and enhances the efficacy of adoptive T-cell transfer in breast cancer. Cancer Res (2014) 74(1):104-18. doi:10.1158/0008-5472.CAN-13-1545

26. Sampson JH, Aldape KD, Archer GE, Coan A, Desjardins A, Friedman AH, et al. Greater chemotherapy-induced lymphopenia enhances tumor-specific immune responses that eliminate EGFRvIII-expressing tumor cells in patients with glioblastoma. Neuro Oncol (2011) 13(3):324-33. doi:10.1093/ neuonc/noq157

27. Ueha S, Yokochi S, Ishiwata Y, Ogiwara H, Chand K, Nakajima T, et al. Robust antitumor effects of combined anti-CD4-depleting antibody and anti-PD-1/PD-L1 immune checkpoint antibody treatment in mice. Cancer Immunol Res (2015) 3(6):631-40. doi:10.1158/2326-6066.CIR-14-0190

28. Ghiringhelli F, Menard C, Puig PE, Ladoire S, Roux S, Martin F, et al. Metronomic cyclophosphamide regimen selectively depletes CD4+CD25+ regulatory $\mathrm{T}$ cells and restores $\mathrm{T}$ and $\mathrm{NK}$ effector functions in end stage cancer patients. Cancer Immunol Immunother (2007) 56(5):641-8. doi:10.1007/ s00262-006-0225-8

29. Alizadeh D, Larmonier N. Chemotherapeutic targeting of cancer-induced immunosuppressive cells. Cancer Res (2014) 74(10):2663-8. doi:10.1158/ 0008-5472.CAN-14-0301

30. Gadgeel SM, Stevenson J, Langer CJ, Gandhi L, Borghaei H, Patnaik A, et al. Pembrolizumab (pembro) plus chemotherapy as front-line therapy for advanced NSCLC: KEYNOTE-021 cohorts A-C. J Clin Oncol (2016) 34(15_suppl):9016. doi:10.1200/JCO.2016.34.15_suppl.9016

31. Langer CJ, Gadgeel SM, Borghaei H, Papadimitrakopoulou VA, Patnaik A, Powell SF, et al. Carboplatin and pemetrexed with or without pembrolizumab for advanced, non-squamous non-small-cell lung cancer: a randomised, phase 2 cohort of the open-label KEYNOTE-021 study. Lancet Oncol (2016) 17(11):1497-508. doi:10.1016/S1470-2045(16)30498-3

32. Borghaei H, Langer CJ, Gadgeel S, Papadimitrakopoulou VA, Patnaik A, Powell SF, et al. Updated results from KEYNOTE-021 cohort G: a randomized, phase 2 study of pemetrexed and carboplatin (PC) with or without pembrolizumab (pembro) as first-line therapy for advanced nonsquamous NSCLC. Ann Oncol (2017) 28. doi:10.1093/annonc/mdx440.052

33. Garon EB, Rizvi NA, Hui R, Leighl N, Balmanoukian AS, Eder JP, et al. Pembrolizumab for the treatment of non-small-cell lung cancer. $N$ Engl J Med (2015) 372(21):2018-28. doi:10.1056/NEJMoa1501824

34. Reck M, Rodriguez-Abreu D, Robinson AG, Hui R, Csoszi T, Fulop A, et al. Pembrolizumab versus chemotherapy for PD-L1-positive non-small-cell lung cancer. N Engl J Med (2016) 375(19):1823-33. doi:10.1056/NEJMoa1606774

35. Gandhi L, Rodriguez-Abreu D, Gadgeel S, Esteban E, Felip E, De Angelis F, et al. Pembrolizumab plus chemotherapy in metastatic non-small-cell lung cancer. N Engl J Med (2018) 378(22):2078-92. doi:10.1056/NEJMoa1801005

36. Paz-Ares LG, Luft A, Tafreshi A, Gumus M, Mazieres J, Hermes B, et al. Phase 3 study of carboplatin-paclitaxel/nab-paclitaxel (Chemo) with or without 
pembrolizumab (Pembro) for patients (Pts) with metastatic squamous (Sq) non-small cell lung cancer (NSCLC). J Clin Oncol (2018) 36(Suppl; abstr 105).

37. Rizvi NA, Hellmann MD, Brahmer JR, Juergens RA, Borghaei H, Gettinger S, et al. Nivolumab in combination with platinum-based doublet chemotherapy for first-line treatment of advanced non-small-cell lung cancer. J Clin Oncol (2016) 34(25):2969-79. doi:10.1200/JCO.2016.66.9861

38. Gettinger SN, Hellmann MD, Shepherd FA, Antonia SJ, Brahmer J, Chow LQ, et al. First-line monotherapy with nivolumab (NIVO) in advanced nonsmall cell lung cancer (NSCLC): safety, efficacy, and biomarker analyses. Eur J Cancer (2015) 51:S632.

39. Paz-Ares L, Brahmer J, Hellmann MD, Reck M, O’Byrne K, Borghaei H, et al. CheckMate 227: a randomized, open-label phase 3 trial of nivolumab, nivolumab plus ipilimumab, or nivolumab plus chemotherapy versus chemotherapy in chemotherapy-naive patients with advanced non-small cell lung cancer (NSCLC). Ann Oncol (2017) 28. doi:10.1093/annonc/mdx091.064

40. Hossein B, Matthew DH, Luis GPA, Suresh SR, Martin R, Kenneth JB, et al. Nivolumab (Nivo) + platinum-doublet chemotherapy (chemo) vs chemo as first-line (1L) treatment (Tx) for advanced non-small cell lung cancer (NSCLC) with <1\% tumor PD-L1 expression: results from CheckMate 227. J Clin Oncol (2018) 36(Suppl; abstr 9001).

41. Liu SV, Camidge DR, Gettinger SN, Giaccone G, Heist RS, Hodi FS, et al. Atezolizumab (atezo) plus platinum-based chemotherapy (chemo) in nonsmall cell lung cancer (NSCLC): update from a phase Ib study. J Clin Oncol (2017) 35(15_suppl):9092.

42. Weiss GJ, Waypa J, Blaydorn L, Coats J, McGahey K, Sangal A, et al. A phase Ib study of pembrolizumab plus chemotherapy in patients with advanced cancer (PembroPlus). Br J Cancer (2017) 117(1):33-40. doi:10.1038/bjc.2017.145

43. Govindan R, Szczesna A, Ahn MJ, Schneider CP, Gonzalez Mella PF, Barlesi F, et al. Phase III trial of ipilimumab combined with paclitaxel and carboplatin in advanced squamous non-small-cell lung cancer. J Clin Oncol (2017) 35(30):3449-57. doi:10.1200/JCO.2016.71.7629

44. Patel SP, Kim DW, Bassett RL, Cain S, Washington E, Hwu WJ, et al. A phase II study of ipilimumab plus temozolomide in patients with metastatic melanoma. Cancer Immunol Immunother (2017) 66(10):1359-66. doi:10.1007/ s00262-017-2030-y

45. Reck M, Luft A, Szczesna A, Havel L, Kim SW, Akerley W, et al. Phase III randomized trial of ipilimumab plus etoposide and platinum versus placebo plus etoposide and platinum in extensive-stage small-cell lung cancer. J Clin Oncol (2016) 34(31):3740-8. doi:10.1200/JCO.2016.67.6601

46. Yamazaki N, Uhara H, Fukushima S, Uchi H, Shibagaki N, Kiyohara Y, et al. Phase II study of the immune-checkpoint inhibitor ipilimumab plus dacarbazine in Japanese patients with previously untreated, unresectable or metastatic melanoma. Cancer Chemother Pharmacol (2015) 76(5):969-75. doi:10.1007/s00280-015-2870-0

47. Liu X, Gibbons RM, Harrington SM, Krco CJ, Markovic SN, Kwon ED, et al. Endogenous tumor-reactive CD8(+) T cells are differentiated effector cells expressing high levels of CD11a and PD-1 but are unable to control tumor growth. Oncoimmunology (2013) 2(6):e23972. doi:10.4161/onci.23972

48. Pulko V, Harris KJ, Liu X, Gibbons RM, Harrington SM, Krco CJ, et al. B7-h1 expressed by activated CD8 T cells is essential for their survival. J Immunol (2011) 187(11):5606-14. doi:10.4049/jimmunol.1003976

49. Reck M, Bondarenko I, Luft A, Serwatowski P, Barlesi F, Chacko R, et al. Ipilimumab in combination with paclitaxel and carboplatin as first-line therapy in extensive-disease-small-cell lung cancer: results from a randomized, double-blind, multicenter phase 2 trial. Ann Oncol (2013) 24(1):75-83. doi:10.1093/annonc/mds213

50. Lesterhuis WJ, Salmons J, Nowak AK, Rozali EN, Khong A, Dick IM, et al. Synergistic effect of CTLA-4 blockade and cancer chemotherapy in the induction of anti-tumor immunity. PLoS One (2013) 8(4):e61895. doi:10.1371/ journal.pone. 0061895

51. Ogawara D, Soda H, Iwasaki K, Suyama T, Taniguchi H, Fukuda Y, et al. Remarkable response of nivolumab-refractory lung cancer to salvage chemotherapy. Thorac Cancer (2018) 9(1):175-80. doi:10.1111/1759-7714.12543

52. Park SE, Lee SH, Ahn JS, Ahn MJ, Park K, Sun JM. Increased response rates to salvage chemotherapy administered after PD-1/PD-L1 inhibitors in patients with non-small cell lung cancer. J Thorac Oncol (2018) 13(1):106-11. doi:10.1016/j.jtho.2017.10.011
53. Yan Y, Cao S, Liu X, Harrington SM, Bindeman WE, Adjei AA, et al. CX3CR1 identifies PD-1 therapy-responsive CD8+ T cells that withstand chemotherapy during cancer chemoimmunotherapy. JCI Insight (2018) 3(8): 97828. doi:10.1172/jci.insight. 97828

54. Yan Y, Failing J, Leontovich AA, Block MS, McWilliams RR, Kottschade LA, et al. The mayo clinic experience in patients with metastatic melanoma who have failed previous pembrolizumab treatment. ASCO Meet Abstr (2016) 34(15_suppl):e21014.

55. Aguilera JV, Paludo J, Bangalore A, Failing J, McWilliams RR, Kottschade LA, et al. Chemoimmunotherapy combination after PD-1 inhibitor failure to improve clinical outcomes in metastatic melanoma patients. JClin Oncol (2018) 36(Suppl; abstr 9558)

56. Leontovich AA, Dronca RS, Suman VJ, Ashdown ML, Nevala WK, Thompson MA, et al. Fluctuation of systemic immunity in melanoma and implications for timing of therapy. Front Biosci (Elite Ed) (2012) 4:958-75. doi: $10.2741 / \mathrm{e} 433$

57. Chang CL, Hsu YT, Wu CC, Lai YZ, Wang C, Yang YC, et al. Dose-dense chemotherapy improves mechanisms of antitumor immune response. Cancer Res (2013) 73(1):119-27. doi:10.1158/0008-5472.CAN-12-2225

58. Sumimoto H, Imabayashi F, Iwata T, Kawakami Y. The BRAF-MAPK signaling pathway is essential for cancer-immune evasion in human melanoma cells. J Exp Med (2006) 203(7):1651-6. doi:10.1084/jem.20051848

59. Khalili JS, Liu S, Rodriguez-Cruz TG, Whittington M, Wardell S, Liu C, et al. Oncogenic BRAF(V600E) promotes stromal cell-mediated immunosuppression via induction of interleukin-1 in melanoma. Clin Cancer Res (2012) 18(19):5329-40. doi:10.1158/1078-0432.CCR-12-1632

60. Knight DA, Ngiow SF, Li M, Parmenter T, Mok S, Cass A, et al. Host immunity contributes to the anti-melanoma activity of BRAF inhibitors. JClin Invest (2013) 123(3):1371-81. doi:10.1172/JCI66236

61. Sapkota B, Hill CE, Pollack BP. Vemurafenib enhances MHC induction in BRAF(V600E) homozygous melanoma cells. Oncoimmunology (2013) 2(1):e22890. doi:10.4161/onci.22890

62. Wilmott JS, Long GV, Howle JR, Haydu LE, Sharma RN, Thompson JF, et al. Selective BRAF inhibitors induce marked T-cell infiltration into human metastatic melanoma. Clin Cancer Res (2012) 18(5):1386-94. doi:10.1158/ 1078-0432.CCR-11-2479

63. Cooper ZA, Juneja VR, Sage PT, Frederick DT, Piris A, Mitra D, et al. Response to BRAF inhibition in melanoma is enhanced when combined with immune checkpoint blockade. Cancer Immunol Res (2014) 2(7):643-54. doi:10.1158/2326-6066.CIR-13-0215

64. Rosenbaum MW, Bledsoe JR, Morales-Oyarvide V, Huynh TG, MinoKenudson M. PD-L1 expression in colorectal cancer is associated with microsatellite instability, BRAF mutation, medullary morphology and cytotoxic tumor-infiltrating lymphocytes. Mod Pathol (2016) 29(9):1104-12. doi:10.1038/modpathol.2016.95

65. Ebert PJR, Cheung J, Yang Y, McNamara E, Hong R, Moskalenko M, et al. MAP kinase inhibition promotes $\mathrm{T}$ cell and anti-tumor activity in combination with PD-L1 checkpoint blockade. Immunity (2016) 44(3):609-21. doi:10.1016/j.immuni.2016.01.024

66. Hu-Lieskovan S, Mok S, Homet Moreno B, Tsoi J, Robert L, Goedert L, et al. Improved antitumor activity of immunotherapy with BRAF and MEK inhibitors in BRAF(V600E) melanoma. Sci Transl Med (2015) 7(279):279ra41. doi:10.1126/scitranslmed.aaa4691

67. Ribas A, Hodi FS, Callahan M, Konto C, Wolchok J. Hepatotoxicity with combination of vemurafenib and ipilimumab. N Engl J Med (2013) 368(14): 1365-6. doi:10.1056/NEJMc1302338

68. Amin A, Lawson DH, Salama AK, Koon HB, Guthrie T Jr, Thomas SS, et al. Phase II study of vemurafenib followed by ipilimumab in patients with previously untreated BRAF-mutated metastatic melanoma. J Immunother Cancer (2016) 4:44. doi:10.1186/s40425-016-0148-7

69. Ribas A, Butler M, Lutzky J, Lawrence DP, Robert C, Miller W, et al. Phase I study combining anti-PD-L1 (MEDI4736) with BRAF (dabrafenib) and/ or MEK (trametinib) inhibitors in advanced melanoma. J Clin Oncol (2015) 33(15_suppl):3003.

70. Minor DR, Puzanov I, Callahan MK, Hug BA, Hoos A. Severe gastrointestinal toxicity with administration of trametinib in combination with dabrafenib and ipilimumab. Pigment Cell Melanoma Res (2015) 28(5):611-2. doi:10.1111/pcmr.12383 
71. Deken MA, Gadiot J, Jordanova ES, Lacroix R, van Gool M, Kroon P, et al. Targeting the MAPK and PI3K pathways in combination with PD1 blockade in melanoma. Oncoimmunology (2016) 5(12):e1238557. doi:10.1080/ 2162402X.2016.1238557

72. Kaneda MM, Messer KS, Ralainirina N, Li H, Leem CJ, Gorjestani S, et al. PI3Kgamma is a molecular switch that controls immune suppression. Nature (2016) 539(7629):437-42. doi:10.1038/nature19834

73. Seifert AM, Zeng S, Zhang JQ, Kim TS, Cohen NA, Beckman MJ, et al. PD-1/ PD-L1 blockade enhances T-cell activity and antitumor efficacy of imatinib in gastrointestinal stromal tumors. Clin Cancer Res (2017) 23(2):454-65. doi:10.1158/1078-0432.CCR-16-1163

74. Jackson SP, Bartek J. The DNA-damage response in human biology and disease. Nature (2009) 461(7267):1071-8. doi:10.1038/nature08467

75. Farmer H, McCabe N, Lord CJ, Tutt AN, Johnson DA, Richardson TB, et al. Targeting the DNA repair defect in BRCA mutant cells as a therapeutic strategy. Nature (2005) 434(7035):917-21. doi:10.1038/nature03445

76. Lord CJ, Ashworth A. PARP inhibitors: synthetic lethality in the clinic. Science (2017) 355(6330):1152-8. doi:10.1126/science.aam7344

77. Rosado MM, Bennici E, Novelli F, Pioli C. Beyond DNA repair, the immunological role of PARP-1 and its siblings. Immunology (2013) 139(4): 428-37. doi:10.1111/imm.12099

78. Lee JM, Cimino-Mathews A, Peer CJ, Zimmer A, Lipkowitz S, Annunziata CM, et al. Safety and clinical activity of the programmed death-ligand 1 inhibitor durvalumab in combination with poly (ADP-ribose) polymerase inhibitor olaparib or vascular endothelial growth factor receptor 1-3 inhibitor cediranib in women's cancers: a dose-escalation, phase I study. J Clin Oncol (2017) 35(19):2193. doi:10.1200/JCO.2016.72.1340

79. Konstantinopoulos PA, Waggoner SE, Vidal GA, Mita MM, Fleming GF, Holloway RW, et al. TOPACIO/Keynote-162 (NCT02657889): a phase 1/2 study of niraparib + pembrolizumab in patients (pts) with advanced triplenegative breast cancer or recurrent ovarian cancer (ROC)-results from ROC cohort. J Clin Oncol (2018) 36(suppl; abstr 106).

80. Ott PA, Hodi FS, Buchbinder EI. Inhibition of immune checkpoints and vascular endothelial growth factor as combination therapy for metastatic melanoma: an overview of rationale, preclinical evidence, and initial clinical data. Front Oncol (2015) 5:202. doi:10.3389/fonc.2015.00202

81. Mansfield AS, Nevala WK, Lieser EA, Leontovich AA, Markovic SN. The immunomodulatory effects of bevacizumab on systemic immunity in patients with metastatic melanoma. Oncoimmunology (2013) 2(5):e24436. doi:10.4161/onci.24436

82. Agostino NM, Saraceni C, Kincaid H, Shi W, Nevala WK, Markovic S, et al. A prospective evaluation of the role of vascular endothelial growth factor (VEGF) and the immune system in stage III/IV melanoma. Springerplus (2015) 4:186. doi:10.1186/s40064-015-0951-5

83. Nevala WK, Vachon CM, Leontovich AA, Scott CG, Thompson MA, Markovic SN, et al. Evidence of systemic Th2-driven chronic inflammation in patients with metastatic melanoma. Clin Cancer Res (2009) 15(6):1931-9. doi:10.1158/1078-0432.CCR-08-1980

84. Manning EA, Ullman JG, Leatherman JM, Asquith JM, Hansen TR, Armstrong TD, et al. A vascular endothelial growth factor receptor-2 inhibitor enhances antitumor immunity through an immune-based mechanism. Clin Cancer Res (2007) 13(13):3951-9. doi:10.1158/1078-0432.CCR07-0374

85. Terme M, Pernot S, Marcheteau E, Sandoval F, Benhamouda N, Colussi O, et al. VEGFA-VEGFR pathway blockade inhibits tumor-induced regulatory T-cell proliferation in colorectal cancer. Cancer Res (2013) 73(2):539-49. doi:10.1158/0008-5472.CAN-12-2325

86. Rini BI, Stein M, Shannon P, Eddy S, Tyler A, Stephenson JJ Jr, et al. Phase 1 dose-escalation trial of tremelimumab plus sunitinib in patients with metastatic renal cell carcinoma. Cancer (2011) 117(4):758-67. doi:10.1002/ cncr. 25639

87. Hodi FS, Lawrence D, Lezcano C, Wu X, Zhou J, Sasada T, et al. Bevacizumab plus ipilimumab in patients with metastatic melanoma. Cancer Immunol Res (2014) 2(7):632-42. doi:10.1158/2326-6066.CIR-14-0053

88. Wallin JJ, Bendell JC, Funke R, Sznol M, Korski K, Jones S, et al. Atezolizumab in combination with bevacizumab enhances antigen-specific T-cell migration in metastatic renal cell carcinoma. Nat Commun (2016) 7:12624. doi:10.1038/ ncomms 12624
89. Motzer RJ, Powles T, Atkins MB, Escudier B, McDermott DF, Suarez C, et al. IMmotion151: a randomized phase III study of atezolizumab plus bevacizumab vs sunitinib in untreated metastatic renal cell carcinoma (mRCC). J Clin Oncol (2018) 36(6_suppl):578. doi:10.1200/JCO.2018.36.6_suppl.578

90. Formenti SC, Demaria S. Systemic effects of local radiotherapy. Lancet Oncol (2009) 10(7):718-26. doi:10.1016/S1470-2045(09)70082-8

91. Siva S, Callahan J, MacManus MP, Martin O, Hicks RJ, Ball DL. Abscopal [corrected] effects after conventional and stereotactic lung irradiation of non-small-cell lung cancer. J Thorac Oncol (2013) 8(8):e71-2. doi:10.1097/ JTO.0b013e318292c55a

92. Sharabi AB, Lim M, DeWeese TL, Drake CG. Radiation and checkpoint blockade immunotherapy: radiosensitisation and potential mechanisms of synergy. Lancet Oncol (2015) 16(13):e498-509. doi:10.1016/S1470-2045(15)00007-8

93. Ahn GO, Tseng D, Liao CH, Dorie MJ, Czechowicz A, Brown JM. Inhibition of Mac-1 (CD11b/CD18) enhances tumor response to radiation by reducing myeloid cell recruitment. Proc Natl Acad Sci U S A (2010) 107(18):8363-8. doi:10.1073/pnas.0911378107

94. Kozin SV, Kamoun WS, Huang Y, Dawson MR, Jain RK, Duda DG. Recruitment of myeloid but not endothelial precursor cells facilitates tumor regrowth after local irradiation. Cancer Res (2010) 70(14):5679-85. doi:10.1158/0008-5472.CAN-09-4446

95. Gupta A, Probst HC, Vuong V, Landshammer A, Muth S, Yagita H, et al. Radiotherapy promotes tumor-specific effector $\mathrm{CD} 8+\mathrm{T}$ cells via dendritic cell activation. J Immunol (2012) 189(2):558-66. doi:10.4049/jimmunol.1200563

96. Burnette BC, Liang H, Lee Y, Chlewicki L, Khodarev NN, Weichselbaum RR, et al. The efficacy of radiotherapy relies upon induction of type I interferondependent innate and adaptive immunity. Cancer Res (2011) 71(7):2488-96. doi:10.1158/0008-5472.CAN-10-2820

97. Camphausen K, Moses MA, Menard C, Sproull M, Beecken WD, Folkman J, et al. Radiation abscopal antitumor effect is mediated through p53. Cancer Res (2003) 63(8):1990-3.

98. Lee Y, Auh SL, Wang Y, Burnette B, Wang Y, Meng Y, et al. Therapeutic effects of ablative radiation on local tumor require CD8+ T cells: changing strategies for cancer treatment. Blood (2009) 114(3):589-95. doi:10.1182/ blood-2009-02-206870

99. Takeshima T, Chamoto K, Wakita D, Ohkuri T, Togashi Y, Shirato H, et al. Local radiation therapy inhibits tumor growth through the generation of tumor-specific CTL: its potentiation by combination with Th1 cell therapy. Cancer Res (2010) 70(7):2697-706. doi:10.1158/0008-5472.CAN-09-2982

100. Barker HE, Paget JT, Khan AA, Harrington KJ. The tumour microenvironment after radiotherapy: mechanisms of resistance and recurrence. Nat Rev Cancer (2015) 15(7):409-25. doi:10.1038/nrc3958

101. Kim JY, Son YO, Park SW, Bae JH, Chung JS, Kim HH, et al. Increase of NKG2D ligands and sensitivity to NK cell-mediated cytotoxicity of tumor cells by heat shock and ionizing radiation. Exp Mol Med (2006) 38(5):474-84. doi: $10.1038 / \mathrm{emm} .2006 .56$

102. Reits EA, Hodge JW, Herberts CA, Groothuis TA, Chakraborty M, Wansley EK, et al. Radiation modulates the peptide repertoire, enhances MHC class I expression, and induces successful antitumor immunotherapy. J Exp Med (2006) 203(5):1259-71. doi:10.1084/jem.20052494

103. Gameiro SR, Ardiani A, Kwilas A, Hodge JW. Radiation-induced survival responses promote immunogenic modulation to enhance immunotherapy in combinatorial regimens. Oncoimmunology (2014) 3:e28643. doi:10.4161/ onci. 28643

104. Matsumura S, Wang B, Kawashima N, Braunstein S, Badura M, Cameron TO, et al. Radiation-induced CXCL16 release by breast cancer cells attracts effector T cells. J Immunol (2008) 181(5):3099-107. doi:10.4049/jimmunol. 181.5.3099

105. Klug F, Prakash H, Huber PE, Seibel T, Bender N, Halama N, et al. Lowdose irradiation programs macrophage differentiation to an iNOS(+)/M1 phenotype that orchestrates effective $\mathrm{T}$ cell immunotherapy. Cancer Cell (2013) 24(5):589-602. doi:10.1016/j.ccr.2013.09.014

106. Deng L, Liang H, Burnette B, Beckett M, Darga T, Weichselbaum RR, et al. Irradiation and anti-PD-L1 treatment synergistically promote antitumor immunity in mice. J Clin Invest (2014) 124(2):687-95. doi:10.1172/JCI67313

107. Herter-Sprie GS, Koyama S, Korideck H, Hai J, Deng J, Li YY, et al. Synergy of radiotherapy and PD-1 blockade in Kras-mutant lung cancer. JCI Insight (2016) 1:e87415. doi:10.1172/jci.insight.87415 
108. Demaria S, Kawashima N, Yang AM, Devitt ML, Babb JS, Allison JP, et al. Immune-mediated inhibition of metastases after treatment with local radiation and CTLA-4 blockade in a mouse model of breast cancer. Clin Cancer Res (2005) 11(2 Pt 1):728-34.

109. Park SS, Dong H, Liu X, Harrington SM, Krco CJ, Grams MP, et al. PD-1 restrains radiotherapy-induced abscopal effect. Cancer Immunol Res (2015) 3(6):610-9. doi:10.1158/2326-6066.CIR-14-0138

110. Barker CA, Postow MA, Khan SA, Beal K, Parhar PK, Yamada Y, et al. Concurrent radiotherapy and ipilimumab immunotherapy for patients with melanoma. Cancer Immunol Res (2013) 1(2):92-8. doi:10.1158/2326-6066. CIR-13-0082

111. Lopez-Martin JA, Arance AM, De La Cruz-Merino L, Illescas A, Valduvieco I, Berrocal A, et al. Ipilimumab and radiation in patients with unresectable melanoma brain metastases: a multicenter, open label, phase-2, Spanish melanoma group (GEM) study (NCT-2013-001132-22). J Clin Oncol (2018) 36(Suppl; abstr 9546).

112. Shaverdian N, Lisberg AE, Bornazyan K, Veruttipong D, Goldman JW, Formenti SC, et al. Previous radiotherapy and the clinical activity and toxicity of pembrolizumab in the treatment of non-small-cell lung cancer: a secondary analysis of the KEYNOTE-001 phase 1 trial. Lancet Oncol (2017) 18(7):895-903. doi:10.1016/S1470-2045(17)30380-7

113. Antonia SJ, Villegas A, Daniel D, Vicente D, Murakami S, Hui R, et al. Durvalumab after chemoradiotherapy in stage III non-small-cell lung cancer. N Engl J Med (2017) 377(20):1919-29. doi:10.1056/NEJMoa1709937

114. Levy A, Massard C, Soria JC, Deutsch E. Concurrent irradiation with the anti-programmed cell death ligand-1 immune checkpoint blocker durvalumab: single centre subset analysis from a phase 1/2 trial. Eur J Cancer (2016) 68:156-62. doi:10.1016/j.ejca.2016.09.013

115. Tang C, Welsh JW, de Groot P, Massarelli E, Chang JY, Hess KR, et al. Ipilimumab with stereotactic ablative radiation therapy: phase I results and immunologic correlates from peripheral T cells. Clin Cancer Res (2017) 23(6):1388-96. doi:10.1158/1078-0432.CCR-16-1432

116. Hiniker SM, Reddy SA, Maecker HT, Subrahmanyam PB, RosenbergHasson Y, Swetter SM, et al. A prospective clinical trial combining radiation therapy with systemic immunotherapy in metastatic melanoma. Int J Radiat Oncol Biol Phys (2016) 96(3):578-88. doi:10.1016/j.ijrobp.2016.07.005

117. Yuan Z, Fromm A, Ahmed KA, Grass GD, Yang GQ, Oliver DE, et al. Radiotherapy rescue of a nivolumab-refractory immune response in a patient with PD-L1-negative metastatic squamous cell carcinoma of the lung. J Thorac Oncol (2017) 12(9):e135-6. doi:10.1016/j.jtho.2017.04.029

Conflict of Interest Statement: The authors declare that the research was conducted in the absence of any commercial or financial relationships that could be construed as a potential conflict of interest.

Copyright (C) 2018 Yan, Kumar, Finnes, Markovic, Park, Dronca and Dong. This is an open-access article distributed under the terms of the Creative Commons Attribution License (CC BY). The use, distribution or reproduction in other forums is permitted, provided the original author(s) and the copyright owner(s) are credited and that the original publication in this journal is cited, in accordance with accepted academic practice. No use, distribution or reproduction is permitted which does not comply with these terms. 